\title{
Teaching Conflict Resolution through General Education at University: Preparing Students to Prevent or Resolve Conflicts in a Pluralistic Society
}

\author{
Elly Malihah ${ }^{1}$, Siti Nurbayani ${ }^{1} \&$ Supriyono $^{2}$ \\ ${ }^{1}$ Program in Sociology of Education, Faculty of Social Sciences Education (FPIPS), Universitas Pendidikan \\ Indonesia, Indonesia \\ ${ }^{2}$ Department of General Studies (MKDU), Faculty of Social Sciences Education (FPIPS), Universitas \\ Pendidikan Indonesia, Indonesia
}

Correspondece: Elly Malihah, Faculty of Social Sciences Education, Universitas Pendidikan Indonesia, Jalan. Dr. Setiabudhi No. 229 Bandung, Indonesia. E-mail: ellymaililah@gmail.com

Received: November 14, 2014 Accepted: April 20, 2015 Online Published: May 28, 2015

doi:10.5539/ass.v11n12p353 URL: http://dx.doi.org/10.5539/ass.v11n12p353

\begin{abstract}
This research stems from an appreciation of ethnic diversity among university students, and the awareness that differences can result in verbal or physical conflicts. University lecturers have an important role to play in helping prevent and resolve student conflicts. Hence, they are required to create a climate conducive to teaching and learning, where what is taught has meaning in the student's life. In the present research, we focused on "Civic Education"- a course meant to create awareness among students on the importance of nationalism, national identity and peaciful living within society from the Indonesian perspective. To establish how university education can help to develop students into good conflict managers and to understand how they can solve disputes arising from the differences in opinion, this research was carried out in two stages: the first stage involved preliminary information gathering with a view to designing a model for teaching conflict resolution. While the second stage was the implementation phase of the conflict resolution teaching model. The model entailed discussions, practical problem solving skills, and role-playing. The activities carried out comprised of reviewing the literature and course syllabus, collecting information, administering questionnaires, carrying out interviews and finally formulating the model. The interviews were conducted at the campuses of universities prone to conflicts. The researchers employed a qualitative research approach, with the help of a case study method. Data collection techniques comprised of questionnaires, interviews, observations, and document analysis. The findings revealed that: 1) Lecturers lack knowledge and skills concerning conflict resolution and prevention among students; and 2) It was established that the implementation of the conflict resolution model has not been effective among students. Because they do not understand the stages involved in a peaceful conflict resolution or prevention process.
\end{abstract}

Keywords: conflict resolution, diversity, higher education, Indonesia, social harmony

\section{Introduction}

Indonesia is a pluralistic nation with great diversity in its ethnicity, culture, traditions, language, and religion. There are an estimated 250 ethnic groups in the country and its people subscribe to a wide variety of religions. The national motto unity in diversity (Bhinneka Tunggal Ika) has long united the people of Indonesia in their diversity. However, inevitably in the course of history, social conflicts have arisen, many of which have been destructive and created great misery for many people. When social conflicts cannot be resolved through constructive mechanisms, destructive conflict may arise. Knowing how to resolve conflict in peaceful and constructive ways is an extremely valuable skill for individuals and societies.

College or university serves as a social system that should have a favorable climate for promoting conducive teaching-learning. Observation of the current climate in universities suggests that it is not always peaceful and safe, and conflicts often arise. These may take various forms, e.g., horizontal and/or vertical conflicts. A university should be an agent of change for conflict resolution in society. Instead, it appears that many universities in Indonesia have become a fighting arena in which conflicts thrive. 
One of the decrees of the Indonesian Directorate of Higher Education Numbered, No.43/DIKTI/Kep/2006 sets guidelines for implementing higher education courses and one of the conditions is to implement a conflict resolution teaching model. In relation to this, courses can be categorized into three groups: (1) General courses; (2) A group of courses focusing on character development, including Civic Education, Religious Education, and Indonesian language, and (3) Specialization courses. This research aimed to investigate current models for conflict resolution in a university setting; ethnic/cultural background differences that might result in conflicts in this setting; the understanding of general course lecturers concerning conflict resolution; and, the knowledge and skills of lecturers concerning conflict prevention and resolution. Based on these findings we aimed to develop a conflict resolution model that would be implemented in general education in the second year.

\section{Literature Review}

\subsection{Conflict Resolution}

Conflict, in a work setting, may refer to a disagreement between two people/parties that upsets productivity, efficiency, and products (Wall \& Callister, 1995). In daily social interaction, conflict is considered as a disagreement between two people/parties that upsets routine social interaction (Volmer and Binnewies, Sonnentag, and Niessen, 2012). Key theories concerning the source of conflict include:

- Theory of social relation by Somerville (2000): The theory sets out a new approach to understanding society. It also argues that conflict is caused by continuous polarization, mistrust and enemity between different groups in society (Znaniecki, 1965) Theory of human needs by Maslow (1943): The root of conflict is unsatisfied or delayed basic human needs (physical, mental, and social). Common topics concerning these needs are security, identity, acknowledgement, participation, and autonomy (Wahba, \& Bridwell, 1976).

- Theory of principled negotiation by Tenbergen (2001): Conflict is caused by disharmonious positions and differences of opinion concerning the conflict matter.

- Theory of identity by Schlee (2004): In his analysis, it can be concluded that the theory of identity assumes that conflicts stem from threatened identity, often rooted in the loss of a particular aspect or item, or unresolved suffering in the past.

- Theory of inter-cultural misunderstanding interpretation from Saee (2004)'s writing on cross-cultural conflicts: Conflict is caused by incompatibility or dissimilarity in communication of different cultures. Theory of conflict transformation in the perspective of Lederach (1995): It is interpreted that conflicts are caused by inequality and unfairness which manifest as social, cultural, and economic problems.

The phenomenon of violence in universities could be considered as 'the tip of the ice-berg'. The physical, group violence sometimes observed in university settings hints at the bigger problems of society hidden beneath the surface. According to Galtung (Sutanto, 2005, p. 16), conflict is a definite cause of violence, because every form of violence was underpinned by an unresolved conflict. He illustrated this by suggesting that violence is the smoke and conflict is the fire. Galtung further suggested that if conflict manifests in individuals and society as a pathology, a collective psychosis will emerge and ultimately rationality will have no effect. When this happens, polarization will occur and violence can break out (Sutanto, 2005, p. 26). Conflict is seen as the struggle between good and evil, black and white, winning and losing, profit and loss.

Kai Fitthjof and Brand Jacobsen (Sutanto, 2005, p. 35) note that conflict occurs at a range of levels: in an individual, among individuals, in and among societies, nations, and cultures. It is natural, embedded in every activity of social life and impossible to eradicate (Syaifullah, 2006). Although conflict is inevitable and experienced by everyone, not all people have the skill and attitude necessary to positively resolve it. People tend to use a limited set of strategies when faced with a conflict: giving in and accepting the situation humbly; running away from the problem; retaliating with greater power and violence; or resorting to a court of law for legal judgment. These ways have been shown to be ineffective and typically make someone a victim in the process. Even at schools, traditional methods of conflict resolution were punishment-based. According to Johnson and Johnson (1995:35), many researchers believe that punishment-based resolution will not positively solve inter-personal conflict between students and will not result in positive behaviors.

Ineffective ways to manage conflict usually stem from one's opinion concerning conflict. It has been suggested that management of conflict is vital, since prevention of conflict in society may be challenging. Deutsch (1973:12) suggested that rather than debating whether conflict is good or bad, the most important consideration is to handle conflict so that a constructive outcome emerges. Conflict need not always be destructive. Whether or not a conflict is constructive depends on the understanding, skills, and competencies of individuals managing 
conflict, at both intra- and inter-personal levels .Imam B. Prasojo (Lidyasari \& Rolina, 2013) emphasized that: "Conflict can not be avoided; but it can be managed, the potential of the conflict can be transformed. However, poor management can turn it into open conflict. A conflict is just like a football game among children; it is organized just like a game. However, it should also be noted that an unorganized conflict can also turn into an open conflict." Thus, conflicts traditionally viewed in a negative light, have the potential to be organized in a way that could make them constructive.

There are two crucial aspects required for conflict prevention and resolution. First, conflict management capacity is needed, including adequate skill and knowledge of conflict resolution and prevention. Second, critical awareness of the society and government concerning conflict resolution and prevention is required. Social institutions, both civil and public (government), typically lack these requirements, even though they are a pre-requisite for creating peace. Preventing violence that arises through conflict, by means of educational programs is also important, according to research from the Carnegie Commission on deadly conflict prevention. The commission found that: (1) various forms of conflict could be prevented; (2) the need for conflict prevention was urgent; and (3) conflict prevention has a high chance of success. However, a problem frequently found in conflict prevention is that conflict occurs in the absence of any cultural, educational, and pedagogic prevention. There is a conflict-solving movement called Alternative Dispute Resolution (ADR) aimed at facilitating cultural, educational and pedagogic interventions. Using this type of conflict resolution as an educational program has important long term value because students are the future drivers of the social structure, and should maintain a culture of peace and anti-violence (Suyanto, 2005).

Schools have considered that conflict resolution skills are urgently required for their students. In a discussion of the role of counselors in the $21^{\text {st }}$ century, it was stated that one of the urgent themes of future counseling is 'conflict resolution counseling.' Johnson and Johnson (1996) suggested, "Most students do not know how to manage their conflict constructively." Meanwhile, the Centers for Disease Control and Prevention noted that violence had reached an 'epidemic' proportion, and that every student should be involved in a conflict resolution program. American Counseling Association established a comprehensive conflict Resolution Program to promote a safe school environment that permits optimal personal growth and learning. Through this program, it is believed that to handle conflicts in a school or university, a more manageable approach to developing a comprehensive conflict resolution is required (Garner, 2008).

There are various conflict resolution programs available, developed under various names like Conflict Resolution Education, Peace Education, Peacemaking, Violence Prevention, and Violence Reduction. According to Crawford and Bodine (1996), some of the conflict resolution programs developed at schools include: conflict resolution training, peer mediation programs, peaceable classrooms and schools, and community mediation centers. All these programs provide students with the opportunity to understand the importance of: (1) realizing that conflict is a natural reality of life that can be resolved peacefully; (2) developing awareness of one's responses toward conflict and of others' responses towards conflict; (3) learning and practicing conflict resolution principles and skills to reach a peaceful conclusion; and (4) empowering one's self individually and cooperatively to be responsible for peaceful conflict resolution and apply it in daily life.

\subsection{Conflict Interaction Patterns}

According to Wijono (Irianto, 2011, p. 20) the characteristics of conflict are: 1) There are at least two parties (individuals or groups), involved in a conflicting interaction; 2) There is a controversy or opposing view between at least two parties in their pursuit of goals and playing of roles; or there are conflicting values or norms; 3 ) The interaction is characterized by behavioral symptoms designed to nullify each other, to diminish and suppress the other party to gain benefits (e.g., status, position, responsibilities, fulfillment of various physical needs including clothes, food, and wealth, or benefits such as cars, houses, or money); and, fulfillment of socio-psychological needs (e.g., sense of security, confidence, love, acknowledgement, and self-actualization); 4) Confronting actions arise as a result of unresolved conflict; and 5) Disequilibrium occurs as a result of each party's effort to gain position, social status, authority, power, self-esteem, and achievement.

The theory of conflict according to Dahrendorf (1959), and Coser (1956) was founded on social fact paradigm, i.e., the structural functional theory and the more moderate conflict theory. These two theories are both holistic, and see society as a whole unit consisting of interrelated parts. Another similarity between the two theories is that both tend to focus on the variables emphasized by other theories. The point is that conflict could contribute to integration and, in contrast, integration could also give birth to conflict.

Conflict can be divided into two types: personal (individual) and interpersonal (inter-individual) conflict. Pickering (Priliantini, 2008, p. 27) described these two types of conflict in further detail. Personal conflict is an 
internal emotional turmoil, e.g., when an individual is required to finish a job or to meet certain expectations, but his/her experience, interest, goals, and values are insufficient to satisfy the demand. Interpersonal conflict occurs between two individuals, and occurs in every society. It cannot be obliterated, but can be managed to yield constructive changes. As Cuff (Irianto, 2011, p. 23) noted, no matter how sharp a conflict is, there can still be a subjective awareness that prevails and ensures it does not destroy the existing relationship. Blau (1967:15) stated that a social structure is a quantitative spread of community members in different, but interrelated, social positions.

\subsection{The Concept of Conflict Management}

Conflict resolution is a process of analyzing and solving problems by considering individual and group needs, e.g., identity and acknowledgement, and institutional changes necessary to satisfy the needs. Ross (1997) stated that conflict management refers to steps taken by the actors or a third party to direct the disagreement towards a certain result that might produce a final result of conflict resolution, and might create positive, creative, agreeable, or aggressive peace. Fisher (2001:7) used the term of conflict transformation to illustrate the situation, using such descriptions: 1) Conflict prevention is aimed at preventing the emergence of hard conflict; 2) Conflict solving desires to end violence through peaceful agreement; 3) Conflict management strives to restrict and prevent violence by urging positive behavioral changes of the involved parties; 4) Conflict resolution aims to handle the sources of conflict and build new lasting relationships between all parties; and 5) Conflict transformation aims to solve the source of wider social and political conflict and to change the negative force of war into a positive social and political force.

\subsection{Ethnicity and Culture}

Ethnicity is not a new issue in the national life of countries around the world. Isiksal (2002) noted "the ethnic root of nationalism fell into the agenda of international relations theory, particularly since the 1970s, when resurgence of ethnic nationalism has been witnessed in many parts of the world." This shows that ethnicity has been a consistent issue in the history of many nations. Isiksal added, "today, it is widely acknowledged that ethnicity plays a crucial role in nationalism." This is the case in Indonesia, where "the historical experience of Indonesia concerning nationalism, particularly those related to ethnicity, was very complex" (Azra, 2006, p. 7). The complexity was not only caused by the different historical experiences in the course of nationalism development, it also arose because of Indonesia's highly pluralistic society. The ethnographic map of Indonesia is very complex. Indonesia is inhabited by large numbers of ethnic groups that, in spite of their physical-biological similarities, demonstrate substantial cultural and linguistic differences.

The concept of ethnicity derives from the Ancient Greek 'etnos'. In Ancient Greek, etnos was defined as a group of people that had similar cultural and biological characteristics and acted in a similar pattern. From this, other definitions like ethnic community or ethnic group emerged, although to date this definition has failed to provide a complete and comprehensive definition of ethnic group (Tilaar, 2007, p. 4).

Handleman (in Tilaar, 2007, p. 12) distinguished four stages of development in human cultural communities: 1) Ethnic category: one's interrelationship with society is a loose bond that serves to illustrate that there are cultural differences between one's group and the outside world; 2) Ethnic network: an organized interaction among the members of an ethnic group so that within the network, members can exchange resources; 3) Ethnic association: members developed similar interests and formed political organizations in collective statements; and 4) Ethnic society: the society had a fixed territory and was bound to its political organization, such as nation-state. In this level various (diverse) ethnicities grouped together.

\subsection{Understanding Cultural Differences}

Moran (cited by Mulyana, 1998, p. 57) is of the view: "Humans were born in generations with a genetic map, and the cultural genetic maps of the generations before us influenced each other. As our geo-physical environment affected us, the social institutions of home, school, and government provided a cultural context that affected our behaviors."

Because culture shapes the identity of a group of people, we can identify the cultural aspects that make one group of people different from other groups. One of the ways to do this is by investigating the group and its aspects, including: 1) communication and language; 2) appreciation and acknowledgment; 3) relationships; and 4) values and norms. Further, the anthropologist, Brown (also cited in Mulyana, 1998, p. 61) suggests: "People of different cultures felt happy, interest, worried, or ashamed of different things, because they perceived situations based on different premises. The learned culture and tradition demanded honesty from its member but was more flexible towards others." 
A culture contains a system of goals and values (Soekanto, 1975, p. 21). With values, the beliefs of people in a certain cultural environment concerning what was right, appropriate, and good were determined. The system of values was an important factor, because it was the factor that determined all behaviors of an individual. Koentjoroningrat (1980:190) provided the following definition of cultural values: “... a concept of what was in the mind of most members of a certain society concerning what they considered valuable, significant, and important in life; which could serve as a guidance that provide aim and orientation of life for the members of that society."

The cultural values held by a society take root in an individual for a long time and are reflected through actions and behaviors. These values influence the behaviors of an individual and a societal group. Human behavior is a product of socio-cultural heritage, not a product of biological factors shared by parents to children. Socio-cultural environment is a factor that determines the attitude and behavior of an individual, based on cultural habit and belief. Witherington (Buchori, 1983, p. 140) explained that: "Habit was a uniformed way of acting or behaving, obtained through repeated learning, which in the end became fixed and automatic. Habitual behavior did not need concentration and focus to be performed."

Habit is not something people are born with and it does not happen in an instant. Habits are formed over time. One of the learning theories that emphasized the importance of habituation is the 'stimulus-response' theory. A response is strengthened if it is accompanied by feelings of happiness or satisfaction, which would make the individual repeat the action. Habit could be formed through practice, repetition, and learning (Natawidjaja, 1977, p. 20).

\subsection{The Role of Intercultural People}

To shape intercultural people at a national level, the following efforts are required: 1) The use of national language in formal forums, such as in educational institutions, governmental/public and private offices; 2) Fair representation of culture (art) through electronic media, particularly television; 3) Fair socialization in educational institutions, and public and private offices; 4) Inter-ethnic contact through students, employee, and youth exchange; 5) Inter-ethnic marriages; and 6) Evenly-distributed development by the government. These efforts cannot occur in isolation. All parties need to cooperate together. However, each individual should be given the freedom to do whatever they need to do to achieve this goal.

\subsection{Ethnic Identity Changes}

There are two approaches concerning ethnic identity. The first is an objective approach (structural), and the second is subjective (phenomenology). The objective perspective sees an ethnic group as being distinguishable from other groups based on cultural characteristics like language, religion, or nationality. The subjective approach formulated ethnicity as a process in which people experienced or felt themselves as a part of an ethnic group, and are identified in this way by other people. This perspective focuses its attention on the bond and sense of ownership perceived by the observed group.

\subsection{Indonesia in 'Bhinneka Tunggal Ika'}

Indonesia illustrates a complex, plural, and heterogeneous culture through the principle of Bhinneka Tunggal Ika (unity in diversity). This means that the country showcases various ways of living, but each of these different ways is integrated into a united nation (Kusumohamidjojo, 2000, p. 45). According to Geertz (in Hardiman, 2002, p. 4), this nation was not only multi-ethnic, but also a battle field of multi-mental influences. Indonesia was a nation with diverse values and characters measures; unified by a great narration of historical, ideological, and religious nature, and was combined into a shared economy and political structure.

It should be considered a blessing if the diversity moved Indonesians together towards a united country, without diminishing the character and identity of each group. However, if the diversity moves without direction — not towards a united Indonesia - because each group emphasizes their own identity (communitarian culture) at the expense of others, problems will occur. Based on the ethnic diversity, Kusumohamidjojo (2000:20) further distinguished the ethnographic dimension of the country by categorizing it into four sub-dimensions: 1) society, 2) culture, 3) phenomenon of plurality and heterogeneity, and 4) dynamic sub-dimension of society and its culture.

\section{Methodology}

This study followed a qualitative approach using the case study method (Faisal, 2008, p. 22) to detail the unique background, nature, and characters of a case, which could then be generalized (Nazir, 2007, p. 65). The data collection techniques included literature review, questionnaire administration, interviews, and analysis of documents. Data analysis followed the steps suggested by Miles and Huberman (2007, p. 20), and consisted of 
three simultaneous activities: data reduction, data display, and conclusion drawing/verification. The research sites were Universitas Hasanudin Makassar, Universitas Muhammadiyah Makassar, Universitas Kristen Indonesia (UKI) Jakarta, and Universitas Persada Indonesia (UPI YAI) Jakarta. All were chosen through purposive sampling.

\section{Results and Discussion}

Conflict is, and has always been, present in life, whether socially or in academic life at a university. When a conflict arises, it cannot be ignored because it will create anxiety and disharmony in social life. University should be a comfortable place to learn. Violence occurring in a university indicates that conflict had begun to creep into the academic society. A conflict resolution and prevention model is needed to realize a harmonious university setting.

The interview and data processing from the questionnaire showed that there was teaching and learning of a conflict resolution model in the general courses at the universities. The conflict resolution model was developed through classroom learning via discussion, problem solving, and role playing. Learning took place by providing opportunities for the students to analyze a problem in their personal or social life in a small group forum. This enabled students to improve their skills in perceiving conflict and in finding the sources of conflict. After the discussion, they were asked to role play as persons in conflict. Students played the roles of negotiator, mediator, and arbitrator. Dugan (Maftuh, 2008, p. 48), noted that negotiation, mediation, and arbitration are non-violent strategies for solving conflict. Through role-playing, the students were engaged in learning to solve personal problems, with support from the social group of their own peers. Role-playing encouraged students to explore problems by acting them out. The model was designed to equip students to face conflict and resolve it peacefully, so that a harmonious learning environment could be created.

Ethnic/cultural background differences of students can spark conflict in a tertiary education setting. Our society is multi-cultural, with people from different ethnic backgrounds joined together in one social life. Drijarkara (Sumatmadja, 1998, p. 16) stated: "Human beings are dynamic. This dynamic never stopped and was always active. Human dynamics connect a person with other people and with his surroundings. This dynamic would keep growing and developing through his life."

Without solidarity among people, each individual will become egotistical. Ethnic and cultural differences among the university students often create conflict, but should be used as an opportunity to learn about others' culture and ethnicity. People may forget that they were born with physical and mental differences ensuring that they will always need help from others. Unwillingness to help others resulted in the forming of social classes (Al-Munawir, 1984, p. 40).

In a multi-ethnic society, respect for each other is vital to avoid conflict. However, ethnic fanaticism, which can create conflict, is inherent and omnipresent in a multi-ethnic society. The ethnic and cultural diversity of Indonesia should not be a divisive factor; rather it should be seen as an enhancement for social interaction in society. Diversity is a gift that should be respected, acknowledged, and valued. The most important thing for us is the willingness to understand, respect, acknowledge, and accept the diversity of our society. Understanding other cultures does not mean we need to implement their ways in our own life. It implies we should respect others and try to live harmoniously with them, united in diversity.

\subsection{Understanding of General Course Lecturers Regarding the Conflict Resolution Model}

Facilitating students' learning about conflict resolution required knowledge and skills linked to conflict understanding, on the part of the lecturers. The results of the field study showed that their understanding was inadequate. As the university is a place where conflict can arise from students' cultural differences, each lecturer is an important figure in determining new concepts of learning. These included learning concepts concerning all problems facing the students, e.g., mass fights among students. As members of academic society, students should be able to exemplify good behavior for broader society. However, violence also happens at university. The students' social life no longer reflects the moral values of society. The lack of solidarity and tolerance could turn students' disagreement into conflict.

Considering that universities are prone to conflict, a learning concept that could be used to solve student conflict was necessary. The development of a conflict resolution model should begin with the lecturer's understanding of the conflicts among the students. Appropriate understanding of conflict would be the foundation to determine the appropriate concept for conflict resolution model learning. The conflicts in universities should be analyzed to find their sources. Galtung (Sutanto, 2005, p. 16) noted that conflict was a sure cause of violence, because in every instance of violence lay an unresolved conflict. 


\subsection{Lecturers' Knowledge and Skill of Conflict Prevention and Resolution in University}

Based on the interviews and data processing, it was found that the lecturers' knowledge and skills concerning conflict prevention and resolution was inadequate. Conflicts happening in university were resolved through sanctions, as regulated by the university. However, these regulations did not provide a way to prevent future conflict. Lecturers' knowledge concerning conflict prevention and resolution is essential to create a safe and comfortable atmosphere. Conflict prevention could be promoted by creating an atmosphere of respect for all students. As noted by Tilaar (2004, p. 94), a multi-cultural society requires an ability to live together in a society full of tolerance and intercultural understanding to build a new harmonious world. Understanding does not mean merely tolerating. Understanding involves critical responses from external sources (parties) to participate in providing support, reasons, acknowledgement, appreciation, knowledge, and empathy in living together as part of an integrated nation.

\subsection{Conflict Resolution Model Implemented in General Courses (MKPK and MBB)}

A conflict resolution model should be taught through discussion, problem solving, and role-playing. The analysis of social problems or violence could be delivered through such a process. In the general courses, the analysis of social problems could be delivered through the Civic Education subject.

Based on the interviews carried out and our data analysis, learning about a conflict resolution model did not take place in general courses. The university used sanctions to punish students that broke university regulations, instead of focusing on future conflict prevention. A more constructive learning process could be implemented using the methods of discussion, problem solving, and role playing. These teaching and learning methods may be the first step in an effort to prevent and resolve conflict among university students. Role playing is a form of educational play used to explain feelings, attitude, behavior, and values with the goal of understanding others' feelings, points of view, and ways of thinking (Depdikbud, 1999, p. 171).

The steps for implementing discussion, problem solving, and role-playing activities were as follows.

The first step:

- Lecturer/students decided on the topic of the problem.

- Students formed groups to discuss the problem.

- Students investigated the topic to analyze the source of the conflict and find the problem.

- Students created problem solving concepts through role playing.

The second step:

- Lecturer asked two or more students to come to the front of the class and role play as conflicting persons.

- Lecturer appointed three other students to be negotiator, mediator, and arbitrator.

- Students analyzed the deficiencies and advantages of the conflict resolution.

The third step:

- Students were asked to provide feedback concerning the difficulties of the conflict resolution.

- Lecturer and students drew conclusions about the process.

These steps could be further developed as necessary. The conflict resolution model aims, at least, to create a more conducive atmosphere for learning. The conflict resolution model implemented in the classroom could also be the source of knowledge and skills for the students to solve conflict outside the classroom.

\section{Conclusion}

The observations, interviews, document study and analysis of relevant theories, led to the following conclusions:

A model for developing conflict resolution in general courses is necessary because conflicts are prevalent in academic societies.

A lecturer understands knowledge and skills concerning conflict resolution are the foundation to develop the conflict resolution learning model.

Implementing the conflict resolution model in general courses through the Civic Education subject was appropriate because the materials of the subject were directly related to social life. 
Focusing on moral and religious values in the university environment could produce a harmonious climate in which everyone would respect each other's cultural differences.

Conflict prevention among university students should stem from the creation of an academic culture that upholds ethical values and obey the norms and rules of the university.

\section{References}

Al-Munawir. (1984). Kamus Arab Indonesia. Yogyakarta: Pondok pesantren Al-Munawir

Azra, A. (2006). Pancasila dan Identitas Nasional Indonesia Perspektif Multikulturalisme; Dalam Restorasi Pancasila, Mendamaikan Politik Identitas dan Modernitas. Bogor: Brigten Press.

Buchori, M. (1983). Teknik-teknik Evaluasi dalam Pendidikan. Bandung, Jemmars.

Coser, L. (1956). The Functions of Social Conflict. New York: The Free Press.

Crawford, D., \& Bodine, R. (1996). Conflict Resolution Education: A Guide to Implementing Programs in Schools, Youth-Serving Organizations, and Community and Juvenile Justice Settings. Program Report Washington, DC: US Dept of Justice Office of Juvenile Justice and Delinquency Prevention

Dahrendorf, R. (1959). Class and class conflict in industrial society. Stanford, CA: Stanford University Press.

Depdikbud. (1999). Kamus Besar Bahasa Indonesia. Jakarta: Balai Pustaka.

Deutsch, M. (1973). The Resolution of Conflict, Constructive and Destructive Process. New Haven and London: Yale University Press

Faisal, S. (2008). Format-format Penelitian Sosial (Dasar-dasar dan Aplikasi). Jakarta: Rajagrafindo Persada.

Fisher, S. (2001). Mengelola konflik, keterampilan dan strategi untuk bertindak. The British Council.

Florian, Z. (1965). Social Relations and Social Roles. The Unfinished Systematic Sociology, San Francisco: Chandler.

Hardiman, F. B. (2002). Belajar dari Politik Multikulturalisme. Pengantar dalam Kymlicka. (2002). Kewargaan Multikultur: Teori Liberal mengenai Hak- hak Minoritas. Terjemahan oleh Edlina Afmini Eddin dari judul Multicultural Citizenship: A Liberal Theory of Minority. Jakarta: LP3ES.

Irianto, P. (2011). Pola interaksi konflik dan reaktualisasi pendidikan karakter. Bandung: Tesis Program studi PKn SPs UPI.

Isiksal, H. (2002). Two Perspectives on the Relationship of Ethnicity to Nationalism: Comparing Gellner and Smith. Alternatives: Turkish Journal of International Relations, 1(1).

Johnshon, D. W., \& dan Johnson, R. T. (1995). Teaching Students to Be Peacemakr. Edina, Minnessota: Interaction Book Company.

Johnshon, D. W., \& dan Johnson, R. T. (1996). Conflict resolution and peer mediation program in elementary and secondary schools: a review of the research, review of educational research.

Koentjoroningrat. (1980). Manusia dan Kebudayaan Indonesia. Jakarta: Gramedia.

Kusumohamidjojo, B. (2000). Kebhinnekaan Masyarakat Indonesia: Suatu Problematik Filsafat Kebudayaan. Jakarta: Grasindo.

Lederach, P. J. (1995). Preparing for Peace: Conflict Transformation Across Cultures. New York: Syracuse University Press.

Lidyasari, T. A., \& Rolina, N. (2013). Pengembangan Panduan Pelatihan Keterampilan Manajemen Konflik (PPKMK) Berbasis Project Method Pada Mahasiswa PGSD FIP UNY, Prosiding Seminar Nasional Dalam Rangka Dies Natalis Ke-49, Universitas Negeri Yogyakarta. Retrieved April 11, 2015, from http://staff.uny.ac.id/sites/default/files/penelitian/aprilia-tina-lidyasari-mpd/b2-semnas-lppm-1.pdf

Maftuh, B. (2008). Pendidikan Resolusi Konflik Membengun Generasi Muda yang Mampu Menyelesaikan Konflik Secara Damai. Bandung: Program Studi Pkn SPs UPI.

Maslow, A. (1943). A Theory of Human Motivation. Psychological Review, 50(4), 370-96. http://dx.doi.org/10. $1037 / \mathrm{h} 0054346$

Miles, M. B., \& dan Huberman, A. M. (2007). Analisis Data Kualitatif: Buku Sumber Tentang Metode-Metode Baru. Jakarta: Universitas Indonesia Press.

Muhmoud, W. A., \& Lawrence, B. G. (1976). Maslow Reconsidered. A Review of Research on the Need 
Hierarchy Theory. Organizational Behavior and Human Performance, 15, 212-240. http://dx.doi.org/10. 1016/0030-5073(76)90038-6

Mulyana, D. (1998). Komunikasi Antar Budaya; Panduan Berkomunikasi Dengan Orang-orang Berbeda Budaya. Bandung: PT. Remaja Rosdakarya.

Nadine, G. E. (2008). Conflict Resolution Programs in the Schools, Professional Counseling Digest. Retrieved April 11, 2015, from http://www.counseling.org/Resources/Library/ACA\%20Digests/ACAPCD-19.pdf

Natawidjaja, R. (1977). Penyuluhan di Sekolah. Jakarta: FA. Hasmar.

Nazir, M. (2007). Metode Penelitian. Jakarta : Ghalia Indonesia.

Peter, B. M. (1967). Exchange and power in social life. New York:Joh Willey and Son.

Priliantini, A. (2008). Hubungan antara gaya menejemen konflik dengan kecenderungan perilaku agresif narapidana usia remaja di lapas pria tanggerang. Psikologi edukasi. Jurnal pendidikan psikologi konseling, 6, 10-20.

Ross, E. W. (1997). The social studies curriculum purposes, problem, and possibilities. New York: State University of New York Press.

Saee, J. (2004). Cross-cultural conflict and conflict resolution. In J. Saee (Ed.), Managing organizations in a global economy: An intercultural perspective (pp. 206-217). USA: South Western.

Schlee, G. (2004). Taking Sides and Constructing Identities: Reflections on Conflict Theory. The Journal of the Royal Anthropological Institute, 10(1), 135-156. http://dx.doi.org/10.1111/j.1467-9655.2004.00183.x

Soekanto, S. (1975). Sosiologi Suatu Pengantar. Jakarta ; Yayasan Penerbitan Universitas Indonesia

Somerville, P. (2000). Social Relations and Social Exclusion: Rethinking Political Economy, Routledge Studies in Governance and Public Policy. London and New York.

Sumatmadja, N. (1998). Manusia Dalam Konteks Sosial. Budaya dan Lingkungan Hidup, Bandung, Alfabeta.

Sutanto, L. (2005). Teori Konseling dan Psikotherapi Perdamaian (Thesis). Malang : PPS UM.

Suyanto. (2005). Pentingnya Program Pendidikan Anti Kekerasan. Retrieved October 8, 2006, from http://www.dikdasmen.org/budayadamai.htm

Syaifullah. (2006). Pendidikan Warga Negara dalam Konteks Global, dalam: Sistem Hukum dan Politik Indonesia Dalam Mewujudkan Negara Demokratis. Jurnal Civicus, 1(6). Tahun 2006. Bandung: Jurusan PKn FPIPS Universitas Pendidikan Indonesia.

Tenbergen, R. (2001). Principled Negotiation and the Negotiator's Dilemma - is the "Getting to Yes "-approach too "soft"? Paper presented at the Interdisciplinary Research Seminar on Negotiation, Harvard University. Retrieved April 11, 2015, from http://www.ifld.de/Education/Material/Negotiation\%20Essay.pdf

Tilaar, H. A. R. (2007). Multikulturalisme: Tantangan-Tantangan Global Masa Depan dalam Transformasi Pendidikan. Jakarta: Grasindo.

Tillaar, H. A. R. (2004). Multikultural; Tantangan-tantangan Global Masa Drepan Dalam Reformasi Pendidikan Nasional. Jakarta Grasindo.

Volmer, J., Binnewies, C., Sonnentag, S., \& Niessen, C. (2012). Do Social Conflicts With Customers at Work Encroach Upon Our Private Lives? A Diary Study. Journal of Occupational Health Psychology, 17(3), 304-315. American Psychological Association. http://dx.doi.org/10.1037/a0028454

Wall, A. J. Jr., Ronda, C., \& Ronda R. (1995). Conflict and Its Management. Journal of Management, 21, 515. http://dx.doi.org/10.1177/014920639502100306

\section{Copyrights}

Copyright for this article is retained by the author(s), with first publication rights granted to the journal.

This is an open-access article distributed under the terms and conditions of the Creative Commons Attribution license (http://creativecommons.org/licenses/by/3.0/). 